\title{
A few thoughts on (non-)ecological advertising
}

\section{Introduction}

In times of constantly growing competition on the market, in order to increase the demand for goods, more and more often entrepreneurs refer to eco-friendly features of their products in advertisements. Therefore, a need arises to establish legal frames preventing misuse and distortion of ecological information in advertisements. Furthermore, a system needs to be created to control if these norms are obeyed. This paper analyses and attempts to assess legal and non-legal norms related to eco-advertising currently enforced in the Polish law. The paper presents the problem of defining the advertisement, especially the notion of non-ecological advertising, as well as the specificity of the message that conveys ecological information. This article raises the issue of using ecological advertising in the entrepreneurs' activity and defines frames of legal liability (civil and criminal) on account of non-ecological advertising. This study also refers to codes of ethics as non-legal norms regulating the question of advertising messages. 


\section{The definition of an advertisement in the Polish law}

These days, from the perspective of advertising regulations, the most significant is the interpretation of the definition of an advertisement. In order to define the notion of the advertisement, one should consider its essence first. The Polish legislation lacks a prescriptive definition of an advertisement. The literature accepts that such notion can be understood broadly or narrowly. In the full sense of this notion, the advertisement encompasses political advertisement, social, economical, as well as all the expressions which produce similar result to the economical advertisement on the market. According to A. Kolodziej, these are all the efforts which aim at promoting certain information about people, companies, ideas, undertakings or things, made to arouse people's interest in them ${ }^{1}$. The narrow sense of the advertisement includes only the economical sphere and refers to activities which aim at arousing potential customer's interest by means of true information about the products and services. R. Skubisz defines the advertisement as the expression which contains an encouragement to purchase the goods or services ${ }^{2}$. For the purpose of this work and on account of the detail of the discussed issues, the narrow understanding of the advertisement has been adopted.

Since the uniform prescriptive definition of the advertisement does not exist, the definitions created by the doctrine are often employed. For instance, the Unfair Competition $\mathrm{Act}^{3}$ does not explain the notion of an 'advertisement' at all and for that reason it is often criticized by the literature on the subject ${ }^{4}$. Based on the act mentioned above, E. Nowinska and M. DuVall assumed that the advertisement should be understood as every intentional action of an entrepreneur aimed at promotion of products

1 A. Kołodziej, Cywilnoprawne konsekwencje wypowiedzi reklamowych w obrocie konsumenckim, in: B. Banaszak, (ed.), Przegląd Prawa i Administracji, vol. LXXIII, p. 27.

2 R. Skubisz, [in:] J. Szwaja (ed.), Ustawa o zwalczaniu nieuczciwej konkurencji. Komentarz, Warsaw 2002, p. 420.

3 The Unfair Competition Act of April 16th, 1993 (Journal of Laws, 03.153 .1503 j.t.).

4 R. Skubisz [in]: J. Szwaja, Ustawa o zwalczaniu nieuczciwej konkurencji. Komentarz, Warsaw 2006, p. 638. 


\section{A few thoughts on (non-)ecological advertising}

or services by pointing at their features in a way which evokes or increases certain needs of the customers (consumers) ${ }^{5}$.

The prescriptive definition of the advertisement is often included in acts governing specific subject matters. An example of an extended definition is the Gambling $\mathrm{Law}^{6}$, where according to article 29 section 6, 'by the advertisement of cylindrical games, card games, dice games, mutual wagering or slot machine games it is understood a public dissemination of trademarks or graphic symbols and other signs related to them, as well as names and graphic symbols of the subjects conducting business activity within the scope of cylindrical games, card games, dice games, mutual wagering or slot machine games and information about places where such games or wagering are organized, as well as opportunities for participation'.

When defining the notion of an advertisement, what needs to be highlighted is the distinction between an advertisement and commercial information. Regulations referring to an advertisement do not include information understood as economic information which is an independent market message, separate from the information included in the advertisement. It is the content of the message that decides whether it should be regarded as information and such content should be limited to a simple message, devoid of any emotional influence, such as assessment ${ }^{7}$. This definition of economic information was approved by the Supreme Court in the judgement of 14 January $1997^{\circ}$. Following this judgement, dissemination of information by an entrepreneur who is the only distributor of a given product is not considered to be an advertisement. Therefore, such action cannot be categorized as an advertisement, including ecological advertisement. Similarly, the Court of Appeals in Warsaw justified in the judgement of 22 May $2003^{9}$ that each advertisement involves information, however, not every information is an advertisement. The advertisement, as opposed to information, is subjective and based on encouraging or urging.

5 E. Nowińska, M. Du Vall, Ustawa o zwalczaniu nieuczciwej konkurencji. Komentarz, Warsaw 2010, p. 262.

6 The Gambling Law of 19 November 2009 (Journal of Laws, 09.201.1540).

7 Ibidem, p. 261.

8 The Judgement of the Supreme Court of 14 January 1997, I CKN 52/96, OSNC 1997 no. 6-7 item 78 .

9 The Judgement of the Court of Appeals in Warsaw of 14 January 1997, I ACa 1893/01, OSA 2004, no 10, item 36. 


\section{Specificity of the notion of advertisement in article 80 of the Environmental Protection Act}

For the purpose of such a complex law as the Environmental Protection Act (further referred to as the EPA) ${ }^{10}$ which regulates a special matter, conditioned by the subject of protection, i.e. the environment, the notion of an advertisement needs to be specified more precisely by introducing the definition of non-ecological advertisement. Such a definition can be drawn from article 80 of the EPA, if a non-ecological advertisement is considered a contario to be a message which includes content promoting consumption model contradictory to the rules of environment protection and sustainable development, especially such message which uses images of wild nature to promote products and services having negative effect on the environment. The legislator's intention was to create a solution limiting the use of the wild nature areas to advertise services which have negative influence on the environment. In practice, the major problem is to specify what kinds of products have, in fact, a negative effect on the environment. Some members of audience may regard car selling as a negative effect on the environment, since cars emit exhaust fumes harmful to the environment, while others may find the promotion of tobacco products non-ecological ${ }^{11}$. Hence, the demands de lege ferenda have appeared in the literature to point out objective, universal criteria which would specify the notion of 'negative influence on the environment ${ }^{12}$. As the notion is vague, the court needs to decide every single time whether a given advertising message has an adverse influence on the environment. For example, the Court of Appeals in Warsaw decided in the judgement of 28 March $2010^{13}$ that it is not forbidden to use an image of wild nature in an advertisement of food, beer to be more exact. According to the Court, the prohibition of using the image of wild nature to promote products or services having negative impact on the environment refers only to 'an advertisement promoting a consumption model which, along with the adverse influence on the environment, destroys it, degrades

\footnotetext{
April 2001, Journal of Laws of 2008 No. 25, item 150 with amendments.

K. Gruszecki, Prawo ochrony Środowiska. Komentarz, Warsaw 2008, p. 237.

12 Ibidem.

13 The Judgement of the Court of Appeals in Warsaw, VI ACa 621/09.
} 


\section{A few thoughts on (non-)ecological advertising}

and leads to disturbances in ecological balance'. This is an example of how essential it seems to specify this notion in the law.

Referring to the nature of non-ecological advertising, it needs to be pointed out that the EPA regulates only the situations where the content being advertised contradicts the rules of environment protection and sustainable development. It does not, however, include situations when the message in an advertisement informs that the product is 'natural' or ,ecofriendly' while, in fact, it is not. Such an advertisement is considered unreliable, which leads to the provisions of the Unfair Competition Act and the norms of the Advertising Standards Association's Code, which will be discussed later on.

It is worth mentioning that the adherence to the requirements for ecological advertisement is currently supervised by social organizations, the ecological ones in particular. This is a subject enhancement, comparing to the majority of regulations in the EPA, which refers to strictly ecological organizations. The doctrine includes an opinion that allowing social organizations to control potentially non-ecological advertisements has never appeared within the regulations of the EPA. This, however, alludes to the previously binding article 39 of the EPA ${ }^{14}$. According to article 80 of the EPA, social organizations are allowed to appeal to the right administrative bodies to take measures which would withdraw the advertisement or any other type of promotion of the product or service, if such an advertisement or type of promotion contradicts article 80 . This structure was enforced in the amendment of 3 October 2008 which aimed at increasing the citizens' participation in protection of the environment. This is certainly a favourable solution, as it enhances the control over the advertisements in Poland, especially the ones where the image of wild nature promotes products and services harmful to the environment. However, the problem may appear with practical execution of this provision, since the legislator did not specify which administrative bodies social organizations should appeal to. It is accepted that administrative bodies should be identified according to separate regulations, thus radio and TV commercials should be subject to the Chairman of the National Broadcasting Council ${ }^{15}$.

14 M. Górski, M. Pchałek, W. Radecki, J. Jerzmański, M. Bar, J. Jendrośka, S. Urban, Prawo ochrony środowiska. Komentarz, Warsaw 2011, p. 286.

15 Ibidem. 


\section{The use of ecological advertisement in promoting entrepreneurs' activity - requirements and limitations}

An entrepreneur who launches a product into the market has a number of information obligations to fulfil, including the ones provided in the EPA. According to article 167 section 1 of the EPA, the product should contain information about the consumption of fuel or operating materials, the degree of emission related to the use of the product, the instructions for environment-friendly use, disassembly and reuse or neutralization of the product. This obligation, according to article 80 of the EPA, also applies to an advertising, where a potential customer should be clearly informed about the product features mentioned above. This means that an advertisement cannot differ content-wise from the information required on the product launch. The clarity of the advertisement means that the message should be created factually and graphically in such a way that it is intelligible also for people who do not have specialist knowledge of environmental protection ${ }^{16}$.

However, the problem arises when it comes to detailed regulations within information requirements in ecological advertisement. The EPA provides numerous references to the directive which should be issued under article $80 \mathrm{a}$ of the EPA. This deed should specify what information has to be included in the advertising message of a product which has features important for environmental protection. Such requirements have not been specified yet. This means that the use of some provisions is significantly limited, for example article 80b of the EPA which legislates the Trade Inspection's supervision of adherence to objective requirements.

\section{Civil liability on account of non-ecological advertisement}

Article 80 of the EPA forbids including in the advertisements the content which promotes consumption model contradictory to the rules of environmental protection and sustainable development. To ensure that

16 Ibidem, p. 285. 


\section{A few thoughts on (non-)ecological advertising}

this provision is observed, sanctions need to be specified. Therefore, the breach of the requirements for ecological advertisement is subject to two liability regimes - civil and criminal. The civil liability regulations in the EPA have been formulated in much broader scope than in the previously binding Act on Environmental Protection and Development ${ }^{17}$. This created real instruments for the protection of reliable advertising message. This enhancement is a result of the axiological understanding of the environment as a common good. When it comes to preventing non-ecological advertising, the ecological organizations gained a special right and now they can apply to the court to withdraw the advertisement or other kind of promotion of the product or service, if this advertisement or promotion contradicts article 80 of the EPA which provides detailed requirements for the ecological advertisement. It is a slightly modified form of a classic instrument of civil liability, nonetheless, it still remains such an instrument. This structure enables to actively oppose, by means of a civil trial, such advertising activity which contradicts the requirements for environmental protection. Furthermore, apart from the claim to withdraw the ecological advertisement, an ecological organization can also cite the regulations of the civil code referring to the protection of personal rights. Each nonecological behaviour, aside from the evident disturbance of the environment as the common good, may potentially violate the personal rights of a private subject, which then allows referring to the norms included in articles 23 and 24 of the Civil Code. This allows a natural person to join a lawsuit. All people who are exposed to destructive for the environment influences are entitled to lodge the above mentioned claims. This is another instrument of the common citizens' initiative within civil law protection of the environment and, at the same time, it enhances control over advertisements being carried out within the law. However, because of vague depiction of this structure and its marginal significance for the objective lawsuit, it should not be expected to be applied in practice.

The right of action belongs here only to an ecological organization, which is understandable on account of the nature of a potential lawsuit against the party contravening article 80 of the EPA and having the capacity to be a party in a given civil case. The interpretation problem, appearing in the views of the doctrine supporters, is to specify the subject which has the

17 The Act on Environmental Protection and Development of 31 January 1980 (Journal of Laws of 1994, No. 49 item 196 with amendments). 


\section{Edyta Dolegowska}

capacity to be a party in a given civil case. Therefore, the questions is, whether the action should be brought against the broadcaster of an advertisement or against the provider of a product or service whose business is to sell the product or service.

The doctrine on the subject provides two separate stands on this matter. The first stand recognizes that one should be able to lodge the claims against both the producer and the entrepreneur publishing the advertisement. According to this view, it is advisable to introduce individual approach depending on the matter the courts are to rule upon ${ }^{18}$. According to the other, less popular stand represented by B. Rakoczy, only an entrepreneur publishing an advertisement should be liable for contravening the article on account of the legal and material basis narrowed down to withdrawing or limiting the broadcast of the advertisement ${ }^{19}$. This stand is focused on the ratio legis of the institution which aims at withdrawing the advertisement. The solution where an individual claim to withdraw the advertisement needs to be lodged against every single broadcaster is considered irrational by the opponents of this stand ${ }^{20}$. Nevertheless, it needs to be pointed out that lawsuit-wise, from the purely practical point of view, B. Rakoczy's stand may turn out to be beneficial for the party having the right of action. The chance of winning the case is bigger in a few individual legal disputes than in one collective lawsuit on the same matter.

\section{Criminal liability on account of non-ecological advertisement}

The liability provided for in the EPA concerns not only the civil aspects. The criminal liability has been also provided for in detail. It refers to sanctions of not observing the requirements for ecological advertisement which result from the Act. Such 'non-ecological behaviour' in an advertising message are considered equal to offences, pursuant to article 361 of the EPA. This means that the penalty for such behaviours is provided directly by the

18 K. Gruszecki, Prawo ochrony..., p. 668-669.

19 B. Rakoczy, Pojęcie sprawy gospodarczej z zakresu ochrony środowiska, Przegląd Sądowy 4, Warsaw 2003, p. 77.

20 K. Gruszecki, Prawo ochrony..., p. 669. 


\section{A few thoughts on (non-)ecological advertising}

Code of Petty Offences ${ }^{21}$. Articles 19-24 of the Code provide for: custody, restriction of liberty or a fine. However, in the subject of the non-ecological advertisement, the regulations only provide for a fine. The instructions for the criminal provisions referring to the non-ecological advertisement stipulate the violation of the requirements of article 80 of the EPA related to the advertisement of products having direct impact on the environment. In this case, the value protected by the law is the reliability of the promotion or advertisement which should comply with all the requirements for the protection of the environment ${ }^{22}$. This means that when introducing a product into the market, an entrepreneur is obliged to inform clearly about the product features, otherwise the criminal provisions should apply. What needs to be pointed out here is the type of the subjects which can be liable for the above mentioned offences. In accordance with the Code of Petty Offences, only natural persons are considered to be such subjects. Therefore, the conclusion can be drawn that the natural persons will bear responsibility for the legal persons they represent and act on behalf of. Furthermore, according to article 5 of the Code of Petty Offences, the liability will be shaped only on the basis of the guilt of the liable subject, which is in opposition to the broader civil liability also providing for strict liability.

It needs to be noted that a on numerous occasions a legal loophole in the doctrine has been noticed which refers to criminal liability for not including in the advertisement or promotional material any information required by article 80 a section 2 of the EPA. This liability, provided for in article 332a section 2 of the EPA, is illusory, as the catalogue of information required for the advertisement should be specified in the directive issued in accordance with the article 80 a section 2 of the EPA. Meanwhile, such directive has not been issued so far. It means that in this case the sanctioning norm functions without the sanctioned norm ${ }^{23}$. Moreover, in this case it is not specified, who should be liable for the infringements. However, it seems logical that it should be the producer of the products being the subject of an advertising activity. Such conclusion can be drawn on the basis of the subject of protection included in this article and the instruction for the regulation - in the end, it is the producer who is obliged to include the information

21 The Code of Petty Offences of May 20th, 1971 (Journal of Laws, 10.46.275 j.t.).

22 M. Górski, Prawo ochrony..., p. 1146.

23 K. Gruszecki, Prawo ochrony..., p. 672. 
in the advertisement, as he aims at selling the products by promoting them in media.

\section{Non-ecological advertisement as an advertisement contradictory to the provisions of law - liability in the Unfair Competition Act}

The above mentioned regulations refer directly to the ecological advertisement. However, the analysis of such advertisement shall be considered within the scope of the advertisement contradictory to the provisions of law in the context of the Unfair Competition Act. Not adhering to the requirements stated in the EPA means in fact standing in contradiction to the law. This argument refers to the Unfair Competition Act which regulates the specificity of the advertisement contradictory to the law and sets another legal regime for advertising. According to this law, the act contrary to the law or to the accepted principles of morality is considered to be an act of unfair competition, if it threatens or infringes the interest of any other entrepreneur or customer. Prohibition of such advertisement is provided for in the article 16 section 1 subsection 1 of the Unfair Competition Act. It refers to the cases where on the basis of separate provisions a given type of the advertisement is unacceptable, which in case of ecological advertisement is proved correct in the article 80 of the EPA. This article states that the advertisement should not contain any content contradictory to the environment protection rules. The legitimacy of establishing a common structure may cause some doubts, which means a few legal regimes protecting the same good. However, it needs to be noted that in this way not one, but two goods are being protected - the natural environment and the interest of the entrepreneurs. This, in turn, increases the chance of eliminating such a non-ecological behaviour. 
A few thoughts on (non-)ecological advertising

\section{The approach of codes of ethics to ecological advertisement}

The legal provisions mentioned in this paper cannot tackle the whole problem of ecological advertisement. Non-legal norms related to the advertising activity complement the legal measures. By the advertising ethics it is understood the whole of moral norms and rules of conduct adopted in the advertising business, which refer to the relations between an entrepreneur and a consumer, business partners and their competitors ${ }^{24}$. Referring to the definition of ethics, the problem arises when combining the individual interest with the benefit of the majority of the viewers ${ }^{25}$. Free market economy may tempt entrepreneurs to use non-ethical advertising to gain significant profits.

The norms of advertising ethics are provided in appropriate codes of ethics. The infringement of rules of such code does not result in any legal sanctions, however, it has a negative influence on the publicity what is very important in the contemporary free market economy. The acceptance of such codes is voluntary. By signing the ethical code, the entrepreneurs pledge to obey the rules of the code. Observing the rules, honesty and lawfulness of the advertisements has a positive influence on the image of the entrepreneur and it certainlyincreases the customers' trust ${ }^{26}$. The primary aim of creating such regulations is to prevent reprehensible precedents and settle disputes on one's own, without resorting to the courts.

These days more and more advertising codes of ethics are being created. These codes present an advertisement as a broad notion and therefore, it is any paid form of presenting a product or idea by a given broadcaster. According to M. Grochowski, the advertisement code of ethics should include principles, rules and assumptions of conduct referring to potential recipients of an advertising message ${ }^{27}$. There are two fundamental drawbacks of the codes of ethics. The first one considers the non-legal nature of the codes which prevents them from being universally binding and observed. The other flaw is that the codes are not obeyed effectively,

24 R. Nowacki, Podręcznik. Reklama, Warsaw 2006, p. 63.

25 M. Grochowski, Granice prawne i etyczne reklamy, Opole 2010, p. 196.

26 R. Nowacki, Podręcznik..., p. 64

27 M. Grochowski, Granice..., p. 205. 


\section{Edyta Dolegowska}

since some statements are imprecise and inexact. One may just hope that by signing a given code of ethics, the entrepreneur will obey the provisions stated in this code.

The code which directly refers to the ecological advertising is the code of ethics for advertising, marketing, advertising, distribution, sponsoring activity and promotion of sales, commonly known as the Advertising Standards Association's Code, enforced on 19 April, 200428. It provides a set of rules the entrepreneurs who use ecological advertisement should obey. The body responsible for controlling the adherence to the code is the Advertising Standards Authority with the Advertising Ethics Committee which consists of independent experts on the advertising and marketing activity.

When it comes to the advertisement involving ecological information, the Advertising Standards Association's Code provides a number of regulations stated in the fifth chapter of the Code. According to these provisions, the advertisement cannot infringe public trust in the correctness of actions undertaken within the scope of the environment protection or use the lack of such knowledge of the recipients within the same scope. Furthermore, providing the right to reliable information, the advertising message cannot mislead consumers within the scope of environmental protection, especially it cannot wrongly inform about the eco-friendly features of a products or the advertiser's actions to protect the environment which have not been actually taken. The recipient of an advertisement should receive competent information about the ecological effect of the product. If the message includes only a general phrasing (such as: 'ecologically safe'), the information must be available in the shop/retail outlet, attached to the product or available to the beneficiary in a commonly accessible way. What is more, the advertisement of a specific ecological product cannot wrongfully include within its scope any other products of the advertiser, which do not meet the requirements for eco-friendly products. In the subject of information included in the advertisement, the information needs to correspond with the actual ecological features of the product which are valid throughout the whole time of its use. If such features are temporary, a consumer needs to be informed about it.

The Advertising Standards Association's Code provides two subjectively specific regulations. The first one refers to advertisements showing 


\section{A few thoughts on (non-)ecological advertising}

the reduction of the amount of harmful components in the product or other elements influencing the condition of the natural environment. The information within this scope cannot mislead the consumer or refer to the lack of components or features which do not even apply to a given category of products. Furthermore, the information considering such features may be only used if the amount of a given substance does not exceed the trace amount. Also, the symbols and signs referring to the natural environment may be only used if the advertisement presents their source (circumstances of granting or awarding) and there is no risk of misinterpreting their meaning. They cannot untruthfully suggest that their appearance is connected with the decision of the government administration authority, local government unit or any other institution whose activity is related to the protection of the natural environment. The other regulation involves the advertisements referring to the solid waste management. They are acceptable only if the recommended by the advertisement method of segregating, collecting, processing or disposal of waste is available for the significant number of the beneficiaries. Otherwise, the range and ways of accessing the above mentioned methods need to be specified.

It seems that the discussed above regulation concerning the advertisement which includes ecological information is presented comprehensively and it outlines the limits of the reliable advertising within this scope. However, it needs to be noted that the legal power of this regulation is little. The advertising codes of ethics, as the regulations which are not imposed directly by the legislator, are not typical documents - they are the tools of self-regulation. The Constitution of the Republic of Poland of $1997^{29}$ by setting a closed catalogue of sources of law in Poland does not include the codes of ethics as the binding sources of law. Therefore, pondering if the codes of ethics are the source of law or just a deontological norm, the second assumption shall be regarded as a correct one. However, the signatories of the codes voluntarily respect the rules of ethics provided in the codes and it undoubtedly enhances public trust and increases the demand on the products of a given entrepreneur.

29 1997, Journal of Laws, No 78, item 483 with amendments. 


\section{Edyta Dolegowska}

\section{Conclusion}

It seems that nowadays, in times of strong competition in the market, new, evocative techniques emerge, which are aimed at getting to the recipients of advertisements. Some of the techniques question the classic rules of fair legal affairs by promoting non-ecological behaviours or providing unreliable information about observing the rules of environment protection by the subjects. Thus, it is crucial to introduce clear, legal regulations in order to prevent misuse that is harmful to the environment. A possible need should be considered for making a demand to establish broader regulation related solely to the ecological advertising and its principles. Moreover, unlawful actions within this scope should be pointed out, as well as clear sanctions to be applied if such actions shall take place. Current prescriptive chaos, which is caused by the abundance of legal acts related to ecological advertising, may influence the compatibility of these regulations, thereby causing problems with their practical application. This, in turn, hinders exercising pro-ecological behaviours among the entrepreneurs. 